\title{
Keefektivan Kebijakan E-Learning berbasis Sosial Media pada PAUD di Masa Pandemi Covid-19
}

\author{
Muhdi ${ }^{1}$, Nurkolis $\otimes_{2}$ \\ Manajemen Pendidikan, Universitas PGRI Semarang \\ DOI: $\underline{10.31004 / o b s e s i . v 5 i 1.535}$
}

\begin{abstract}
Abstrak
Masalah penelitian ini adalah bagaimanakah keefektivan rumusan kebijakan e-learning, keefektivan implementasi kebijakan e-learning, dan apa kendala-impelementasi e-learning di PAUD. Tujuan penelitian ini untuk mendeskripsikan keefektivan rumusan kebijakan $e$ learning, keefektivan implementasi kebijakan e-learning, dan kendala implementasi elearning di PAUD. Penelitian ini adalah penelitian kebijakan dengan metode kombinasi concurrent embedded strategy. Penelitian dilakukan di Provinsi Jawa Tengah pada 35 kabupaten/kota, April 2020, responden 1.899 orang dengan standard error 5\%. Teknik pengumpulan data dengan angket, dokumen kebijakan, dan wawancara. Data kuantitatif diolah dengan Pivoting Program MS Excel. Data kualitatif diolah dengan software Nvivo 12+. Pengujian keabsahan data menggunakan triangulasi sumber dan metode. Pengujian kredibilitas dokumen dengan korelasi Pearson dan word frequency. Hasil penelitian menunjukkan bahwa rumusan kebijakan e-learning di PAUD sangat efektif, implementasi kebijakan e-learning di PAUD kurang efektif, dan terdapat tiga kendala implementasi $e$ learning di PAUD yaitu kendala pedagogi, teknologi, dan ekonomi.
\end{abstract}

Kata Kunci: teknologi; pendidikan; internet; kebijakan; paud.

\begin{abstract}
This research problem is the effectiveness of e-learning policy formulation, the effectiveness of e-learning policy implementation, and the obstacles of e-learning in ECE. The research purpose to describe the effectiveness of e-learning policy formulation, the effectiveness of elearning policy implementation, and the constraints of e-learning in ECE. This is a policy research combination of concurrent embedded strategy. The study conducted in 35 districts/cities, Central Java Province, April 2020, 1,899 respondents with standard error 5\%. Data collection techniques using questionnaires, policy documents, and interviews. Quantitative data processed by MS Excel Pivoting. Qualitative data processed with Nvivo $12+$. Data validity testing use source and method triangulation. Testing document credibility with Pearson correlation and word frequency. The results showed that the e-learning policy formulation in ECE very effective, the implementation of e-learning policy in ECE less effective, and there were three obstacles in implementing e-learning in ECE namely pedagogical, technological, and economic constraints.
\end{abstract}

Keywords: technology; education; internet; policy, ece.

Copyright (c) 2020 Muhdi, Nurkolis

$\triangle$ Corresponding author :

Email Address : nurkolis@gmail.com (Jl. Sidodadi Timur No. 24 Semarang 50125)

Received 14 May 2020, Accepted 24 May 2020, Published 28 May 2020 


\section{PENDAHULUAN}

Setelah adanya pandemi Corona Virus Disease 19 (Covid-19) Menteri Pendidikan dan Kebudayaan RI mengeluarkan dua kebijakan melalui Surat Edaran No. 3 tahun 2020 (Kemendikbud, 2020c) dan Surat Edaran No. 4 tahun 2020 (Kemendikbud, 2020d). Kedua kebijakan Mendikbud tersebut terkait pencegahan Covid-19 pada satuan pendidikan dan pelaksanaan kebijakan pendidikan dalam masa darurat penyebaran Covid-19. Kebijakan belajar di rumah itu dikenal sebagai kebajakan belajar jarak jauh dalam jaringan (Daring) atau sering disebut online learning. Kementerian agama juga mengeluarkan kebijakan tentang mekanisme pembelajaran dan penilaian madrasah dalam masa darurat pencegahan penyebaran Covid-19 dengan memanfaatkan kanal e-learning (Kemenag, 2020a).

Artikel ini menggunakan istilah e-learning yang memiliki konsep yang lebih luas dari pada online learning. E-learning bisa berbasis computer atau disebut computer-based learning dan berbasis online learning yaitu pembelajaran dalam rajingan atau disebut Daring. Online learning bisa menggunakan internet yang dikenal dengan internet-based learning dan bisa berbasis website yang dikenal dengan web-based learning yang keduanya menggunakan jaringan online yang saling terhubung terus menerus antara satu pengguna dengan pengguna yang lain. Sementara itu gabungan dari e-learning dan face-to-face learning secara offline disebut pembajaran campuran atau blended learning atau hybrid learning (BuzzettoMore, 2007:29). Di Amerika Serikat disebut pembelajaran online jika memenuhi kriteria minimal $80 \%$ isi pembelajaran disampaikan secara online atau dalam jaringan. Jika online hanya $1-29 \%$ maka disebut pembelajaran web facilitated. Disebut pembelajaran campuran atau disebut hybrid learning jika materi pembelajaran disampaikan secara online $30 \%$ hingga 80\% (Allen dan Seaman, 2013:7).

Maka yang dimaksud dengan e-learning dalam artikel ini adalah pembelajaran yang dilakukan tidak secara tatap muka tetapi pembelajaran jarak jauh dengan bantuan perangkat eloktronik atau gadget seperti deskptop, laptop, atau smart phone yang dimiliki oleh guru dan siswa/orang tua siswa sehingga proses pembelajaran tetap berlangsung dalam situasi pandemi Covid-19.

Dipilihnya istilah e-learning ini karena pada masa pandemi Covid-19 ini kenyataannya proses pembelajaran di Pendidikan Anak Usia Dini (PAUD) tidak dilaksanakan terus menerus di dalam jaringan tapi tidaksakanan secara on dan off. Namun pembelajaran juga tidak dapat dilakukan secara tatap muka dikarenakan adanya larangan mengumpulkan siswa dengan alasan keamanan. E-learning di PAUD berbasis sosial media karena 95\% pelaksanaan pembelajaran menggunakan media sosial berupa WhatsApp.

Seiring berkembangnya teknologi \& informasi dan internet, maka pembelajaran dapat dilakukan secara online. Maka muncullah banyak istilah seperti e-learning yaitu pembelajaran yang menggunakan perangkat elektronik. Pembelajaran yang dilaksanakan dengan jaringan internet atau dengan world wide web disebut online learning atau online education. Pendidikan online menghubungkan siswa dengan materi pelajaran melalui internet (Johnson dan Manning, 2009:10). Ada yang menyebut pendidikan online sebagai pendidikan siber atau cyberspace classroom (Palloff dan Pratt, 2002:20). Kini ada yang memanfaatkan smart phone sebagai sarana pembelajaran maka disebut m-learning atau pembelajaran bergerak (mobile larning) karena guru dan siswa bisa bergerak kemanapun mereka berada.

Surat Edaran Mendikbud No. 3 dan 4 tersebut merupakan kebijakan pendidikan. Kebijakan pendidikan adalah kebijakan publik di bidang pendidikan (Tilaar dan Nugroho, 2009:264). Kebijakan pendidikan adalah alat yang dibuat oleh pemerintah demi terwujudnya perubahan yang lebih baik (Madjid, 2018:12-13). Kebijakan ini dikeluarkan karena kebijakan penyelenggaraan pendidikan face to face tidak bisa dilaksanakan sehingga perlu dibuat kebijakan baru dalam rangka mencapai tujuan yang diinginkan.

Dua kebijakan Mendikbud tersebut menindaklanjuti Peraturan Pemerintah Pengganti Undang-Undang dan Peraturan Pemerintah terkait pananganan Covid-19 merupakan kebijakan publik bidang pendidikan. Kebijakan publik memiliki tujuan yaitu distributif 
versus absortif, regulatif versus deregulatif, serta dinamisasi versus stabilitasi (Nugroho, 2017:172). Kebijakan pendidikan memilikii tiga unsur pokok yaitu adanya masalah, adanya tujuan, dan adanya cara pemecahan masalah (Madjid, 2018: 16-21).

Beberapa aspek yang perlu diperhatikan dalam penyelenggaraan e-learning adalah perencanaan, pengukuran kebutuhan siswa, sistem pendukung, kompetensi pengajar, desain materi, platform yang tepat, dan evaluasi hasil belajar siswa (Lynch, 2002:3-4). Ahli lain berpendapat aspek yang diperhatikan dalam e-learning adalah siswa, guru, materi pembelajaran, teknologi atau platform yang digunakan, dan lingkungan pembelajaran (Inoue, 2007:67). Platform dalam sistem e-lerning yaitu learning management system (LMS) merupakan pembentuk lingkungan belajar virtual (Coates, 2006:43). Tiga aspek utama dalam e-learning yaitu pengembang, pendidik, dan siswa (Pangondian dkk., 2019). E-learning akan berhasil jika memperhatikan akses dan teknologi, pedoman dan prosedur, partisipasi maksimum dari siswa, pembelajaran kolaboratif yang diterapkan guru, dan adanya interaksi (Palloff dan Pratt, 2002:26). Berdasarkan pendapat para ahli di atas maka kebijakan dan implementasi e-learning sebaiknya memperhatikan aspek siswa, guru, sarana pendukung, materi, evaluasi, interaksi, platform teknologi yang digunakan, dan sistem manajemen pembelajaran.

Beberapa hasil penelitian terkait penerapan e-learning dengan berbagai istilah yang digunakan di PAUD menunjukkan hasil dan dampak positif terhadap siswa. Seperti ditulis oleh (Asilestari, 2016; Setyaji dkk., 2015; Panjaitan dkk,. 2015; dan Taufik dkk., 2019). Namun penelitian-penelitian tersebut dalam sekala kecil dan dengan jumlah resnponden sedikit. Sementara itu penelitian ini bersekala besar yaitu tingkat provinsi dengan jumlah resnponden yang jauh lebih banyak. Implementasi kebijakan e-learning masa Covid-19 sedang berlangsung dan belum ada hasil penelitian yang mengungkap keefektivan rumusan kebijakan, keefektivan implementasi kebijakan, dan kendala-kendalanya. Oleh karena itu penelitian ini penting dilakukan karena akan diperoleh hal-hal yang baru dan hasilnya dapat dimanfaatkan untuk penyempurnakan kebijakan khususnya terkait e-learning di PAUD.

Maka rumusan masalah dalam penelitian ini yaitu (a) bagaimanakah keefektivan rumusan kebijakan e-learning di PAUD, (b) bagaimanakah keefektivan implementasi kebijakan e-learning di PAUD, dan (c) apakah kendala-kendala impelementasi $e$-learning di PAUD? Maka tujuan penelitian ini yaitu untuk (a) mendeskripsikan keefektivan rumusan kebijakan e-learning di PAUD, (b) mendeskripsikan keefektivan implementasi kebijakan $e$ learning di PAUD, dan (c) mendeskripsikan kendala-kendala implementasi e-learning di PAUD.

Hasil penelitian ini dapat dimanfaatkan oleh guru dan kepala PAUD dalam mengimplementasi kebijakan e-learning, sebagai masukan kepada Pemerintah dan Pemerintah Daerah dalam memperbaiki kebijakan e-learning, dan memberikan masukan kepada Dinas Pendidikan \& Kebudayaan Kabupaten \& Kota dan Kantor Kementerian Agama Kabupaten \& Kota dalam mengendalikan dan mengawasi implementasi e-learning di PAUD.

\section{METODOLOGI}

Artikel ini berdasarkan hasil penelitian kebijakan dengan metode kombinasi concurrent embedded strategy. Penelitian kebijakan adalah penelitian yang objeknya berupa kebijakan terdiri penelitian tentang kebijakan dan penelitian untuk kebijakan (Nugroho, 2014:54). Penelitian ini termasuk penelitian kebijakan jenis "penelitian tentang kebijakan" karena kebijakan yang diteliti sudah ada yaitu kebijakan belajar di rumah dengan online learning atau e-learning. Metode kombinasi concurrent embedded strategy menggunakan metode penelitian kuantitatif dan kualitatif secara simultan tetapi bobot metodenya berbeda (Sugiyono, 2017:431). Dipilih metode kombinasi concurrent embedded strategy karena bobot metodenya tidak sama. Dari tiga subfokus penelitian, dua diantaranya dianalisis secara kualitatif dan satu dianalisis dengan kuantitatif. 
Penelitian dilakukan di Provinsi Jawa Tengah pada 35 kabupaten dan kota dengan responden 1.899 orang guru PAUD dengan standard error 5\%. Rinciannya 519 orang guru PAUD di bawah Kementerian Agama (Kemenag) dan 1.380 orang guru PAUD di bawah Dinas Pendidikan dan Kebudayaan (Disdikbud). Teknik pengumpulan data dengan angket tertutup dan terbuka yang diedarkan pada bulan April 2020 melalui google form yang tautannya disebarkan melalui grup WhatsApp para guru. Dokumen kebijakan yang dianalisis sebanyak 23 mencakup dokumen Pemerintah dan Pemerintah Daerah. Data dilengkapi dengan wawancara mendalam melalui aplikasi voice di WhatsApp. Sebanyak 23 dokumen tertulis yang digunakan untuk analisis kebijakan terdiri dari 1 Peraturan Pemerintah Pengganti Undang-Undang (Perpu), 1 Peraturan Pemerintah, 1 Keputusan Presiden, 4 kebijakan tingkat Kementerian, 2 kebijakan tingkat Provinsi, dan 14 adalah kebijakan tingkat Pemerintah Kabupaten dan Kota.

Data kuantitatif berupa isian angket tertutup diolah dengan Pivoting di Program MS Excel. Data kualitatif berupa isian angket terbuka, dokumen, dan hasil wawancara diolah dengan software kuantitatif-kualitatif Nvivo 12+. Analisis data kualitatif mengikuti model Miles dan Huberman seperti gambar 1. Pengujian keabsahan data menggunakan triangulasi sumber dan triangulasi metode. Triangulasi sumber dengan mengecek jawaban dari responden berdasarkan isian angket terbuka dan hasil wawancara. Triangulasi metode dengan mengecek jawab responden dari angket, wawancara, dan penelusuran dokumen.

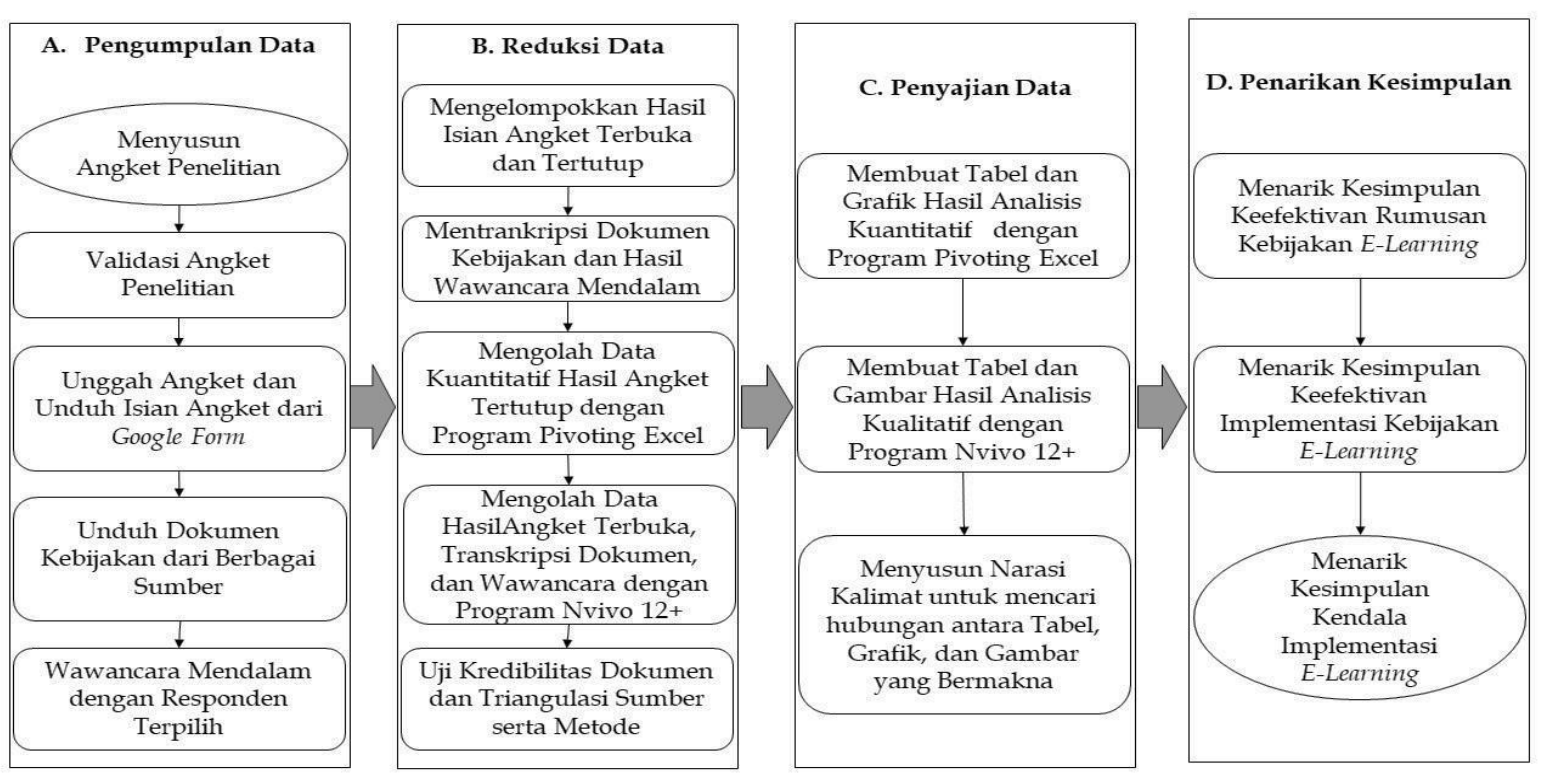

\section{Gambar 1. Langkah-Langkah Penelitian}

Kredibilitas dokumen diolah dengan korelasi Pearson hasilnya menunjukkan bahwa dari 23 dokumen tersebut saling terkait satu dengan yang lain. Dengan software Nvivo 12+ diketahui bahwa nilai korelasi terendah adalah 0,14 dan nilai korelasi tertinggi adalah 0,99. Kredibilitas dokumen juga dicek dengan fasilitas word frequency untuk mengetahui apakah dokumen yang dianalisis sesuai dengan topik dan tujuan penelitian. Hasilnnya kata-kata kunci tertinggi yang ditemukan adakah "pendidikan" ada 346 kata, "sekolah" ada 151 kata, "kesehata"" 112 kata, dan "kebijakan" ada 87 kata yang delengkapnya dapat dilihat pada gambar 2. Dengan demikian semua dokumen yang dianlisis saling terkait dan memiliki kredibilitas sesuai dengan permasalahan penelitian. 




\section{HASIL DAN PEMBAHASAN}

\section{Keefektivan Rumusan Kebijakan E-Learning di PAUD}

Analisis keefektivan rumusan kebijakan e-learning dalam artikel ini menggunakan pendapat Madjid, Nurgroho, dan Sugiyono. Kebijakan pendidikan memiliki tiga unsur pokok yaitu masalah, tujuan, dan cara pemecahan masalah (Madjid, 2018:16-21). Dua diantara tujuan kebijakan publik adalah regulatif atau deregulatif dan dinamisasi atau stabilitasi (Nugroho, 2017:171). Kebijakan yang baik dibuat secara ilmiah, terbuka, adil, tujuannya untuk pemecahan masalah, dan dirumuskan dengan kalimat yang jelas (Sugiyono, 2017:6).

Dokumen kebijakan yang digunakan dalam menganalisis keefektivan rumusan kebijakan e-learning ini adalah yang terkait langsung dengan proses belajar mengajar di sekolah dan madrasah. Ada 3 dokumen utama yang dianalisis yaitu SE Mendikbud No. 3 tahun 2020 (Kemendikbud, 2020c), SE Mendikbud No. 4 tahun 2020 (Kemendikbud, 2020d), dan Nota Dinas Dirjen Pendidikan Islam No. B-686.1/DJ.I/Dt.I.I/PP.00/03/2020 (Kemenag, 2020a). Hasil analisis kualitatif terhadap permasalahan keefektivan rumusan kebijakan ini dapat dirangkum pada tabel 1.

Tabel 1. Analisis Keefektivan Rumusan Kebijakan E-Learning

\begin{tabular}{ll}
\hline \multicolumn{1}{c}{$\begin{array}{c}\text { Unsur dan } \\
\text { Tujuan }\end{array}$} & \multicolumn{1}{c}{ Deskripsi Rumusan Kebijakan E-Learning } \\
\hline Masalah & $\begin{array}{l}\text { Penyebaran Covid-19 di lingkungan pendidikan, dirumuskan berdasarkan data } \\
\text { (Madjid, 2018). } \\
\text { yang lengkap, akurat, dan up to date dari Pemerintah melalui Kementerian } \\
\text { Kesehatan, memperhatikan ketersediaan dan keterjangkauan internet di sekolah } \\
\text { dan masyarakat. }\end{array}$ \\
Tujuan (Madjid, & $\begin{array}{l}\text { Melindungi warga sekolah dari ancaman Covid-19 dan menjamin } \\
\text { keberlangsungan pembelajaran secara e-learning, memiliki tujuan regulatif (yaitu } \\
\text { Nugroho, 2017). }\end{array}$ \\
& $\begin{array}{l}\text { kegiatan pembelajaran dilaksanakan dari rumah dengan e-learning) dan } \\
\text { deregulatif (yaitu tidak dibebani tuntutan menuntaskan seluruh capaian } \\
\text { kurikulum dalam rangka kenaikan kelas maupun kelulusan dan tugas dan } \\
\text { aktivitas belajar di rumah dapat bervariasi antarsiswa sesuai minat masing- } \\
\text { masing siswa), memiliki tujuan mendinamisasi atau menstabilitasi yaitu } \\
\text { menggerakkan para guru untuk belajar e-learning. }\end{array}$ \\
\end{tabular}




\begin{tabular}{|c|c|}
\hline $\begin{array}{l}\text { Unsur dan } \\
\text { Tujuan }\end{array}$ & Deskripsi Rumusan Kebijakan E-Learning \\
\hline $\begin{array}{l}\text { Cara } \\
\text { Pemecahan } \\
\text { Masalah } \\
\text { (Madjid, 2018). }\end{array}$ & $\begin{array}{l}\text { Pembelajaran dilaksanakan dari rumah dengan e-learning, mengatur ulang } \\
\text { penggunaan dana bantuan operasional sekolah, mengatur ulang pelaksanakan } \\
\text { ujian sekolah, membatalkan ujian nasional, mengatur ulang kenaikan kelas dan } \\
\text { penerimaan peserta didik baru, memaksimalkan pemanfaatan UKS, } \\
\text { menyediakan sarana kesehatan untuk cuci tangan, dan menjaga kesehatan diri } \\
\text { dan lingkungan sekolah. }\end{array}$ \\
\hline $\begin{array}{l}\text { Ciri Kebijakan } \\
\text { yang Baik } \\
\text { (Sugiyono, } \\
\text { 2017). }\end{array}$ & $\begin{array}{l}\text { Memiliki tujuan dan tujuan kebijakan jelas, memiliki cara pemecahan masalah, } \\
\text { dibuat secara adil karena berlaku di seluruh wilayah Indonesia, bersifat terbuka } \\
\text { dan fleksibel karena boleh menggunakan plaftorm atau aplikasi yang berbeda. }\end{array}$ \\
\hline
\end{tabular}

Masalah utama munculnya kebijakan e-learning adalah kekhawatiran berkembang dan menyebarnya Covid-19 di lingkungan satuan pendidikan karena virus ini sudah berkembang dan menyebar di masyarakat. Dengan demikian kebijakan ini sudah memenuhi unsur masalah (Madjid, 2018:17). Kebijakan ini telah memenuhi rumusan masalah yang jelas dan ilmiah yaitu berdasarkan data yang lengkap, akurat, dan up to date (Sugiyono, 2017:6) karena kebijakan tersebut dikeluarkan setelah mencermati terus bertambahnya penderita Covid-19 di masyarakat dan memperhatikan ketersediaan akses internet di sekolah dan madrasah. Tujuan kebijakan e-learning adalah untuk melindungi kesehatan warga sekolah dan madrasah dari ancaman Covid-19 dan menjamin keberlangsungan pembelajaran secara e-learning. Dengan demikian ketiga kebijakan tersebut telah memiliki unsur tujuan (Madjid, 2018:19) atau telah memenuhi kebijakan yang baik (Sugiyono, 2017:6) karena kebijakan ini memiliki tujuan dan tujuannya jelas.

Cara pemecahan masalah terkait Covid-19 di satuan pendidikan tertuang dalam SE Mendikbud No. 3 tahun 2020 yaitu "proses pembelajaran dilaksanakan dari rumah dengan e-learning", "mengatur ulang penggunaan dana bantuan operasional sekolah", "mengatur ulang pelaksanakan ujian sekolah", "membatalkan ujian nasional", "mengatur ulang kenaikan kelas dan penerimaan peserta didik baru", "memaksimalkan pemanfaatan Usaha Kesehatan Sekolah (UKS)", "menyediakan sarana kesehatan untuk cuci tangan", serta "menjaga kesehatan diri dan lingkungan sekolah". Dengan demikian kebijakan ini telah memenuhi unsur pemecahan masalah (Madjid, 2018;20). Ketiga kebijakan tersebut telah memenuhi kebijakan yang baik karena telah menyediakan cara pemecahan masalah (Sugiyono, 2017:6).

Kebijakan yang keluarkan oleh Kemendikbud dan Kemenag tersebut telah dibuat secara adil karena dapat diterapkan di seluruh wilayah Indonesia. Kebijakan ini juga bersifat terbuka dan fleksibel karena warga sekolah dan madrasah bisa menggunakan berbagai platform pembelajaran jarak jauh baik yang disediakan langsung oleh kedua kementerian tersebut atau melalui kanal dan penyedia layanan lainnya. Misalnya dalam Nota Dinas Dirjen Pendais Kemenag disebutkan bahwa madrasah dapat menyelenggarakan belajar dari rumah dengan memanfaatkan aplikasi e-learning madrasah melalui https://elearning.kemenag.go.id/web dan atau aplikasi daring lainnya. Dengan demikian kebijakan e-learning ini memenuhi kebijakan yang baik (Sugiyono, 2017:6).

Ditinjau dari sisi tujuan kebijakan e-learning yang tertuang dalam SE Mendikbud No. 4 tahun 2020 (Kemendikbud, 2020d) dan Surat Dirjen Pendais Kemenag (Kemenag, 2020a) telah memenuhi tujuan kebijakan regulatif sekaligus deregulatif. Kebijakan regulatif bersifat mengatur dan membatasi maka dalam kontek kebijakan e-learning ini mengatur agar kegiatan pembelajaran dilaksanakan dari rumah dengan e-learning (Nugroho, 2017:172). Kebijakan ini juga mengatur bahwa pembelajaran di rumah dilaksanakan untuk memberikan pengalaman belajar bermakna bagi siswa, dan difokuskan pada pendidikan kecakapan hidup diantaranya mengenai Covid-19. Kebijakan ini juga bersifat deregulatif karena dinyatakan bahwa e-learning "tidak dibebani tuntutan menuntaskan seluruh capaian 
kurikulum dalam rangka kenaikan kelas maupun kelulusan". Kebijakan ini melonggarkan aturan yang dinyatakan "tugas dan aktivitas belajar di rumah dapat bervariasi antarsiswa sesuai minat masing-masing siswa". Para guru diminta memberi umpan balik kepada siswa secara kualitatif tanpa diharuskan memberi skor kuantitatif hasil belajar siswa.

Kebijakan yang telah memenuhi tujuan regulatif juga ditunjukkan dalam SE Mendikbud No. 3 tahun 2020 (Kemendikbud, 2020c). Tujuan regulatif terlihat dari kalimat "menginstruksikan kepada satuan pendidikan untuk mengoptimalkan peran usaha kesehatan sekolah", "memastikan ketersediaan sarana cuci tangan pakai sabun", dan "memastikan kebersihan ruangan". Kebijakan juga memiliki tujuan deregulatif yang tampak dalam kalimat "memberikan ijin kepada warga satuan pendidikan yang sakit untuk tidak datang di satuan pendidikan", "tidak memberlakukan hukuman bagi yang tidak masuk karena sakit", dan "tidak memberlakukan kebijakan berdasar insentif berbasis kehadiran". Tujuan deregulatif dari Nota Dinas Dirjen Pendais Kemenag juga tampak dalam penyataannya kebijakan terkait ujian akhir madrasah, ujian akhir semester, dan penerimaan peserta didik baru.

Kebijakan Kemendikbud dan Kemenag tersehut juga telah memenuhi tujuan mendinamisasi atau menstabilitasi. Kebijakan mendinamisasi bersifat menggerakkan sumber daya untuk mencapai kemajuan yang dikehendaki (Nugroho, 2017:172). Hal ini terlihat dari jawaban responden yang menunjukkan $82 \%$ guru PAUD mengaku bahwa pandemi Covid-19 ini telah memotivasi mereka untuk belajar menggunakan e-learning dan hanya $18 \%$ saja yang menyatakan tidak termotivasi. Kebijakan tersebut telah menggerakkan guru untuk belajar menguasai teknologi pembelajaran atau teknologi pendidikan. Beberapa data kuantitatif dirangkum pada tebel 2 berikut.

Tabel 2. Pemahanan dan Implementasi E-Learning di PAUD

\begin{tabular}{lcc}
\hline \multicolumn{1}{c}{ Deskripsi Pertanyaan } & \multicolumn{2}{c}{ Alternatif Jawaban 1 Buah } \\
& Ya (\%) & Tidak $(\%)$ \\
\hline 1. Apakah guru tahu kebijakan e-leaning? & 90 & 10 \\
2. Apakah guru tahu kebijakan e-learning dari & 73 & 27 \\
$\quad$ pemerintah berupa surat edaran? & 95 & 5 \\
3. Apakah guru menerapkan kebijakan e-earning? & 19 & 81 \\
4. Apakah guru berpengalaman menerapkan e-learning? & 83 & 17 \\
5. Apakah guru membuat RPP? & 82 & 18 \\
6. Apakah pandemi Covid-19 memotivasi guru untuk & & \\
belajar e-learning? & & \\
\hline
\end{tabular}

Hasil wawancara menunjukkan bahwa belum ada guru PAUD yang pernah mendapatkan pelatihan e-learning dari Dinas Pendidikan dan Kebudayaan (Disdikbud) atau Kemenag. Kondisi pandemi Covid-19 memaksa para guru melaksanakan e-learning karena tidak ada pilihan lain setelah keluarnya kebijakan mengumpulkan masyarakat dan menjaga jarak fisik. Berdasarkan angket terkait pengalaman guru PAUD dalam melaksanakan $e-$ learning sebanyak $81 \%$ guru belum pernah menerapkan e-learning, yang kadang-kadang menerapkan $13 \%$ dan yang sering menerapkan sebanyak $6 \%$. Kemungkinan mereka yang pernah menerapkan e-learning karena pengalamannya saat kuliah atau belajar secara mandiri.

Pengakuan responden tersebut sesuai dengan data Kemenag bahwa hanya 1\% saja siswa yang telah menggunakan e-learning dan sebanyak $22 \%$ guru di lingkungan Kemenag telah menggunkan e-larning, serta 14\% lembaga madrasah telah menggunakan e-learning (Kemenag, 2020b). Detail datanya adalah jumlah total madrasah 82.418 namun lembaga pengguna e-learning 11.289. Jumlah guru madrasah keseluruhan 268.706 orang sedangkan guru pengguna e-learning 59.615 orang. Dilihat dari jumlah siswa madrasah keseluruhan 9.45.198 orang sedangkan jumlah siswa pengguna e-learning 60.401 orang (Kemenag, 2020c). 
Keefektivan rumusan kebijakan e-learning selain ditinjau dari ketiga teori kebijakan tersebut juga bisa dilihat dari pemahaman para pelaksana dan tingkat implementasinya. Sebanyak $90 \%$ guru PAUD mengaku tahu adanya kebijakan e-learning dan 10\% guru tidak tahu. Sebesar $72 \%$ guru mengetahui kebijakan tersebut dari kebijakam Kemendikbud dan Kemenag berupa Surat Edaran dan sisanya dari kebijakan yang lain. Berdasarkan data yang menerapkan e-learning sebanyak $95 \%$ dan yang tidak menerapkan hanya 5\%. Artinya para guru telah mengetahui adanya kebijakan, mengerti isinya, dan melaksanakan kebijakan tersebut.

Berdasarkan analisis terhadap 23 dokumen menunjukkan bahwa Pemerintah Darah, Kantor Kementerian Agama Provinsi, serta Kantor Kementerian Agama Kabupaten dan Kota saling mendukung kebijakan e-learning yang dikeluarkan oleh Pemerintah Pusat. Hal ini dapat dilihat dari tingginya hasil Korelasi Pearson dengan nilai korelasi terendah 0,14 dan nilai korelasi tertinggi 0,99. Temuan ini berbeda dengan temuan Kemendikbud yang menunjukkan 38\% sekolah mengaku tidak mendapat dukungan dari Pemerintah Daerah (Kemendikbud, 2020a: 10). Survey ditingkat guru dilaporkan Federasai Serikat Guru Indonesia (FSGI) dan Komisi Perlindungan Anak Indonesia (KPAI) yang menyatakan 40,2\% guru mengaku tidak mendapatkan bantuan dari sekolah untuk menerapkan pembelajaran di rumah (KPAI, 2020a). Perbedaan ini terjadi karena kemungkinan para guru yang disurvey Kemendikbud dan KPAI tersebut tidak membaca dan mencermati ini berbagai kebijakan yang dikeluarkan oleh Pemerintah Daerah dan instansi terkait.

Dengan demikian dapat disimpulakan bahwa berdasarkan kajian teori dan hasil penelitian menunjukkan bahwa rumusan kebijakan e-learning sudah sangat efektif. Secara teoretis unsur kebijakan sudah terpenuhi, tujuan kebijakan sudah ada dan jelas, serta memenuhi kriteria kebijakan yang baik.

\section{Keefektivan Implementasi Kebijakan E-Learning di PAUD}

Sejak tahun 1980 hingga kini telah berkembang teknologi internet, multimedia interaktif, MOOCs, Social Computing, dan Cloud Computing (Huang dkk., 2019:43-44) yang dapat dimanfaatkan dalam proses belajar mengajar. Teori belajar kontruktivisme telah digeser oleh teori konektivisme dan teknologi pendidikan telah berkembang menjadi lebih interaktif sehingga menuntut perubahan dalam praktik pembelajaran di kelas. Saat ini dikenal sebagai era internet of things (IoT). IoT adalah jaringan yang menghubungkan berbagai elemen dengan kecerdasan perangkat lunak, sensor, dan konektivitas melalui internet (Rayes dan Salam, 2019:2). Sayangnya para guru di Indonesia belum banyak memanfaatkan teknologi informasi dan komunikasi serta internet dalam pembelajaran. Hal ini dapat dilihat dari prosentase guru yang menggunakan fasilitas e-learning di Kemdikbud melalui kanal rumah belajar hanya 9\% dan di Kemenag 22\% (Kemenag, 2020b), sementara itu dilihat dari prosesntasi siswa baik di Kemendikbud dan Kemenag sama-sama 1\%.

Kondisi tersebut menimbulkan pertanyaan, bagaimanakah keefektivan implementasi e-learning di PAUD pada masa pandemic Covid-19 ini? Untuk mengetahuinya maka perlu dibahas dari berbagai sisi seperti kesiapan guru, media yang digunakan, platform teknologi yang digunakan, metode yang dipilih dalam pembelajaran, dan evaluasi yang diterapkan oleh para guru.

Berdasarkan pengalaman guru PAUD sebanyak $81 \%$ belum pernah menerapkan $e$ learning dan mereka juga belum pernah mendapatkan pelatihan e-learning. Karena tidak ada pilihan lain pada Covid-19 ini maka 95\% guru telah menerapkan e-learning dan hanya 5\% yang tidak menerapkannya. Namun ketika guru PAUD diminta untuk menilai kualitas pelaksanaan e-learning yang mereka lakukan hasilnya menunjukkan sebanyak $51 \%$ guru menilai "cukup".

Berdasarkan jawaban responden guru PAUD sebanyak $83 \%$ guru sudah membuat RPP dan 13\% lainnya belum membuat RPP. Mencermati pengalaman pembelajaran dan pelatihan e-learning yang dimiliki guru maka RPP yang dibuat bukanlah untuk kegiatan $e$ - 
learning. Perbedaan mendasar pembelajaran tatap muka dengan membelajaran elektronik adalah dalam hal interaksi pembelajaran. Oleh karena itu RPP yang dibuat guru dalam $e-$ learning harus secara khusus memperhatikan aspek interaksi selama pembelajaran.

Pilihan media pembelajaran, platform yang digunakan, metode pembelajaran, dan evaluasi yang digunakan oleh guru PAUD saat menerapkan e-learning di masa pandemi Covid-19 dapat dilihat pada tabel 3.

\section{Tabel 3. Penerapan E-Learning oleh Guru PAUD}

\begin{tabular}{lcc}
\hline \multicolumn{1}{c}{ Deskripsi Pertanyaan } & \multicolumn{2}{c}{ Alternatif Jawaban Lebih dari 1 } \\
& Terbanyak 1 (\%) & Terbanyak 2 (\%) \\
\hline $\begin{array}{l}\text { 1. Media ang digunakan guru dalam menerapkan } \\
\text { e-leaning? }\end{array}$ & 63-audio visual & 29-visual \\
2. Platform e-learning yang digunakan guru? & 95-whatsapp & 20-google class \\
$\begin{array}{l}\text { 3. Metode yang dugunakan guru dalam } e- \\
\text { earning? }\end{array}$ & 96-penugasan & 39-tanya jawab \\
$\begin{array}{l}\text { 4. Evaluasi yang digunakan guru dalam } \\
\text { menerapkan } \text {-learning? }\end{array}$ & 61-tertulis & 44-portofolio \\
$\begin{array}{l}\text { 5. Penilaian guru terhadap penyelenggaraan } e- \\
\text { learning? }\end{array}$ & 51-cukup baik & 33-baik \\
\hline
\end{tabular}

Ditinjau dari media yang digunakan guru dalam implementasi e-learning, sebagian besar responden memanfaatkan media audio visual untuk menyampaikan pesan dan menerima pesan ke siswa yaitu $63 \%$. Guru yang memanfaatkan media visual $29 \%$, dan teks $5 \%$, serta audio 3\%. Kenyataan tersebut sangat berbeda dengan pernyataan pilihan platform yang digunakan guru dalam pembelajaran. Pengakuan 95\% guru responden menggunakan aplikasi WhatsApp dan khalayak mengetahui bahwa aplikasi ini termasuk aplikasi yang banyak menggunakan teks. Audio visual di WhatsApp juga ada walau penggunaannya tidak maksimal untuk pembelajaran yang interaktif. Hasil penelitian ini senada dengan temuan KPAI dan FSGI yang menyatakan bahwa 83,4\% guru menggunakan medsos (WhatsApp, Line, Facebook, dan Instagram) dalam pembelajaran di rumah secara e-learning (KPAI, 2020b).

Temuan Kemendikbud juga menyatakan bahwa WhatsApp paling banyak digunakan oleh para guru yaitu sebesar $42 \%$, platform kelas maya $16 \%$, telepon atau sms $17 \%$, dan video conference $11 \%$, serta sisanya menggunakan email, aplikasi google form, dan mengunjungi langsung siswa ke rumah-rumah (Kemendikbud, 2020a: 13). Temuan penelitian ini dan temuan Kemendikbud mirip dengan temuan KPAI bahwa komunikasi guru murid dilakukan menggunakan aplikasi pesan singkat sebesar 87,2\%, zoom meeting sebesar 20,2\%, video call WhatsApp sebesar 7,6\%, dan telepon sebesar 5,2\% (CNN Indonesia, 2020).

Media yang digunakan dan platform teknologi yang dipilih berbasis teks tersebut tidak memungkinkan terjadi interaksi intensif. Padahal terdapat tiga tingkatan interaksi siswa dalam e-learning yaitu interaksi dengan konsep, interaksi dengan tugas, dan interaksi dengan orang lain yaitu dengan guru maupun siswa lain (Palloff dan Pratt, 2002:26; dan Juwah, 2006:10). Interaksi siswa dengan konsep adalah kontak siswa dengan konseptualisasi orang lain. Interaksi terjadi antara kerangka pemahaman siswa atas mareti selumnya dengan materi baru serta dengan pemahaman siswa lainnya. Interaksi dengan tugas adalah aplikasi konsep baru yang telah dipahami siswa dalam menjalankan tugas-tugas yang diberikan guru secara bermakna. Interaksi dengan orang lain akan penguji penguasaan konsep baru dengan cara melakukan komunikasi dengan teman-temannya dan guru selama mengerjakan tugas yang dikerjakan.

Dengan media teks jarak jauh melalui WhatsApp tersebut tidak memungkinkan adanya interaksi yang intensif antara siswa dengan guru dan siswa dengan siswa lainnya. Interaksi dengan konsep yang ada di materi pun akhirnya akan terhambat sehingga akan 
banyak kendala dalam menyelesaikan tugas. Selama implementasi e-learning di Indonesia disimpulkan oleh Kemendikbud bahwa belum banyak guru menerapkan pembelajaran yang interaktif (Kemendikbud, 2020a:24). Survey KPAI dan FSGI juga menyimpulkan bahwa $79,9 \%$ siswa merasakan tidak ada interaksi yang intensif antara guru dan siswa. Pada guru tidak menjelaskan materi atau tidak adanya tanya jawab antara guru dan siswa. Para guru hanya memberikan tugas dan setelah itu para guru menagih tugas kepada para siswa (KPAI, 2020b).

Proses interaksi akan terjadi secara maksimal jika media yang dipilihnya tepat. Jjika kondisinya memungkinkan, media audio visual paling berpeluang terjadi interkasi secara maksimal. Sedangkan media audio atau teks saja kurang memberi peluang terjadinya interaksi secara optimal. Misalnya media audio visual berupa komputer interaktif atau CD interaktif akan mengoptimalkan motorik anak menjadi lebih peka dan terasah (Asilestari, 2016). Interaksi yang baik dalam pembelajaran digital dan adanya kepercayaan diri siswa akan berdampak positif terhadap hasil belajar (Panjaitan dkk., 2020). Aspek interaksi ini harus benar-benar diperhatikan karena terkait dengan tingkat kegagalan e-learning yang berada pada kisaran $20-80 \%$. Studi lain menyimpulkan bahwa interaksi adalah salah satu faktor penting yang menentukan keberhasilan e-learning (Rostaminezhad dkk., 2013).

Pilihan platform dan media yang digunakan adalah teks tersebut mempengaruhi pilihan metode yang diterapkan dalam e-learning di PAUD. Karakteristik media mampu mendukung atau sebaliknya membatasi jenis pembelajaran tertentu. Jenis media yang digunakan mensyaratkan strategi, metode, atau pendekatan meningkatkan efektivitas pembelajaran e-learning (Swan, 2003).

Berdasarkan jawaban responen, metode yang digunakan pada e-learning di PAUD adalah $95 \%$ penugasan walaupun dilengkapi dengan metode lainnya seperti percobaan, tanya jawab, curah pendapat, dan diskusi. Temuan senada dilaporkan Kemdikbud bahwa metode yang paling banyak dipilih guru adalah penugasan yaitu sebesar 25\% (Kemendikbud, 2020a:12). Hasil survey FSGI dan KPAI juga mengungkap bahwa metode yang paling banyak dipilih adalah memberikan tugas diakukan oleh 58,8\% guru. Para guru mengakui bahwa 29\% mereka mengakhiri pembelajaran dengan pemberikan tugas yang berat (KPAI, 2020a). Survey KPAI juga mengungkap sebesar 73,2\% siswa merasa berat mengerjakan tugas, dan 26,8\% siswa merasa tidak berat.

Media yang dipilih, platform pembelajaran yang diterapkan, dan metode yang dipilih mempengaruhi jenis evaluasi yang digunakan guru PAUD. Responden mengaku $61 \%$ guru PAUD menggunakan evaluasi tertulis. Para guru juga mengaku menggunakan evaluasi lebih dari satu dan dilengkapi dengan evaluasi lisan, portfolio, dan produk.

Pilihan media, platform, metode, evaluasi, dan interaksi yang rendah saat implementasi e-learning berdampak pada perasaan senang dan tidak senang oleh para siswa dalam pembelajaran. Seperti laporan KPAI bahwa 76,7 \% siswa merasa tidak senang belajar dari rumah, namun ada 23,3\% siswa merasa senang belajar di rumah (CNN Indonesia, 2020). Kementerian Pemberdayaan Perempuan dan Perlindungan Anak (Kemen PPPA) melaporkan hasil survey Forum Anak Nasional (FAN) bahwa 58\% anak merasa tidak senang mengikuti pembelajaran di rumah. Hal ini karena anak sulit berinteraksi dengan teman yang lain (Mashabi, 2020).

Berdasarkan kesiapan para guru, media yang digunakan guru, pilihan platform pembelajaran, metode pembelajaran yang dunakan, proses interaksi pembelajaran, alat evaluasi yang digunakan para guru PAUD, serta perasaan para murid maka dapat disimpulkan bahwa implementasi e-learning di PAUD kurang efektif.

\section{Kendala-Kendala Implementasi E-Learning di PAUD}

Berdasarkan data kualitatif, kendala-kendala yang dialami oleh guru PAUD dalam menerapkan e-learning dapat dirangkum pada tabel 4 berikut. 
Tabel 4. Kendala Penerapan E-Learning di PAUD

Kategori Kendala

1. Kendala Pedagogi

2. Kendala Teknologi

3. Kendala Ekonomi
Bentuk Kendala

Belum mendapatkan pelatihan, belum pengalaman, belum mendapatkan pendampingan, kemampuan TIK rendah, keterbatasan waktu, kurang tepat memilih media, platform, metode, evaluasi, dan rendahnya interaksi pembelajaran, serta kurangnya kedulian orang tua siswa pendampingi anaknya belajar di rumah.

Kurangnya prasarana berupa jaringan internet/wifi, lemahnya sinyar mobile phone, belum dimilikinya perangkat elektronik seperti smartphone, kurangnya kemampuan memanfaatkan perangkat elektronik pintar untuk mendukung e-learning.

Orang tua siswa kehilangan pekerjaan, penghasilan berkurang, tingkat kemiskinan meningkat, serta harga quota internet dan paket data yang tinggi.

Pengakuan para guru tersebut sesuai dengan hasil penelitian sebelumnya bahwa kendala implementasi e-learning yang ditemukan adalah kendala pedagogi dalam menggunakan Teknologi Informasi dan Komunikasi atau TIK (Fauzan dan Pimada, 2018; dan Asiah, 2016), kendala pedagogi dalam menyusun Rencana Pelaksanaan PembelajaranRPP (Sum dan Taran, 2020), kendala pedagogi berupa rendahnya interaksi (Roach dan Lemasters, 2006), kendala pedagogi berupa gangguan mengakses selain materi (Winter dkk., 2010), kendala pedagogi berupa kurangnya kemampuan guru membuat evaluasi (Sari dan Setiawan, 2020), kendala teknologi yaitu ketersediaan akses internet (Harjanto dan Sumunar, 2018; dan Suhartanto, 2010) dan gabungan beberapa kendala (Pangondian dkk., 2019).

Dari analisis implementasi e-learning di atas dan belum efektifnya implementasi di sekolah menunjukkan bahwa para guru PAUD masih mengalami kendala pedagogis. Penyebabnya guru belum pernah mendapatkan pelatihan e-learning, belum pengalaman menerapkan e-learning, dan belum pernah mendapatkan pendampingan secara langsung dalam menerapkan e-learning. Kebenyakan guru menerapkan e-learning dengan cara belajar secara otodidak.

Kendala pegadogi dalam implementasi terkait kurang profesionalnya guru, alokasi waktu yang kurang, dan ada materi pelajaran tidak dapat terapkan ke dalam aplikasi $e$ learning (Asiah, 2016). Para guru juga menghadapi kendala menerapkan TIK dalam pembejaran yaitu masalah kurangnya kemampuan guru mengoperasikan perangkat (Fauzan dan Pimada, 2018).

Kendala pedagogi mulai tampak dari belum mampunya guru menyusun RPP untuk e-learning, memilih media, memilih metode, memilih alat evaluasi, dan menyelenggaran pembelajaran dengan interaksi yang optimal. Banyaknya guru PAUD yang terkendala dalam menyusun RPP tidak hanya dialimi di Provinsi Jawa Tengah juga masih terjadi di tempat lain. Terutama untuk menyusun RPP yang menyenangkan masih minim (Sum dan Taran, 2020). Pembelajaran e-learning tidak mungkin bisa menyenangkan apabila RPP yang disusun tidak menunjukkan interaksi yang menyenangkan.

Kendala pedagogi berupa rendahnya interaksi dan proses pembelajaran ini tidak hanya terjadi di PAUD bahkan tapi juga terjadi di perguruan tinggi. Penurut penelitian $e$ learning di perguruan tinggi juga mengalami kendala interasksi berupa komunikasi tidak tepat waktu, kurang jelasnya harapan atau tujuan pembelajaran, kurang jelasnya tugas yang diberikan bahkan ada kendala keamanan data (Roach dan Lemasters, 2006). Implementasi $e$ learning memiliki sejumlah keuntungan dan kendala. Salah satu kendala terkait pedagogi yaitu dalam mengelola materi pembelajaran dan non-pembelajaran. Ketika siswa sedang belajar dengan e-learning, siswa ada yang mengerjakan tugas yang diberikan oleh guru tapi ada juga yang membuka informasi lain para perangkat pembelajaran yang sedang dibuka (Winter dkk., 2010). 
Kendala pedagogi lainnya yang dialami guru PAUD adalah dalam melaksanakan evaluasi. Penelitian menunjukkan bahwa guru PAUD banyak yang belum mampu melaksanakan penilaian pembelajaran secara berkesinambungan serta tidak bisa membuat penilaiain pembelajaran secara sistematis dan menyeluruh (Sari dan Setiawan, 2020). Padahal penelitian itu dilakukan pada proses pembelajaran konvensional, maka bisa dipastikan guru belum memiliki kemampuan penilaian juga dalam menerapkan e-learning.

Para guru juga banyak yang mengaku belum bisa menggunakan perangkat elektronik dan smartphone untuk mendukung pembelajaran. Artinya kemampuan para guru PAUD di Jawa Tengah dalam menerapkan TIK pada pembelajaran masih kurang. Hal ini berbeda dengan kemampuan guru PAUD di wilayah Jakarta dan Tangerang yang telah memiliki kemampuan TIK dengan cukup baik. Para guru PAUD di dua wilayah tersebut telah mampu memanfaatkan TIK dalam pendidikan dengan cukup baik (Rohita, 2020).

Termasuk kendala pedagogis adalah kemampuan orang tua untuk menggunakan perangkat elektronik dan gadget yang dimilikinya untuk mendukung pembelajaran anak di rumah. Hal ini karena kebanyakan masyarakat menggunakan smartphone untuk bersosial media. Sementara itu dari pihak-pihak terkait seperti Disdikbud dan Kemenag belum ada panduan bagi orang tua dalam mendampingi anaknya belajar pada masa Covid-19 ini. Akhirnya banyak pengakuan orang tua di berbagai media massa bahwa mereka stres selama mendampingi anaknya belajar di rumah.

Jika orang tua siswa punya perangkat elektronik dan gadget ada masalah lain yaitu kepedulian orang tua. Selama masa belajar di rumah faktor keterlibatan orang tua dalam $e$ learning di PAUD mutlak diperlukan. Hasil penelitin menunjukkan bahwa banyak faktor yang mempengaruhi keterlibatan orang tua di PAUD dalam mendidik anak diantaranya faktor status sosial (Irma dkk. 2019). Maka guru perlu tahu status sosial orang tuanya dan mengajak orang tua berpartisipasi lebih aktif mendampingi anak belajar di rumah.

Kendala teknologi yang dialami para guru dan muris atau orang tua murid diantaranya terkait prasarana dan sarana e-learning. Kendala prasarana terkait dengan ketersediaan infrastruktur internet dan jaringan mobile phone. Sementara itu kendala sarana terkait dengan kepemilikan smartphone dialami oleh sebagian orang tua siswa.

Di Indonesia belum ada standar minimum e-learning dari pemerintah dan kualitas pemanfaatan situs e-learning masih kurang. Sehingga kualitas e-learning masih rendah dan penyebabnya adalah infrastruktur dasarnya masih kurang terutama terkait ketersediaan internet (Suhartanto, 2010). Penelitian yang lain mengungkap bahwa selain faktor pedagogi, faktor teknologi adalah penentu keberhasilan implementasi e-learning. Terdapat tiga dimensi sistem yang mencakup tiga hal yaitu serta kualitas institusi dan layanan, kualitas informasi dan pembelajaran, dan kualitas sistem dan infrastruktur (Pangondian dkk., 2019).

Kendala teknololgi ini juga diakui oleh Kemendikbud yang melaporkan bahwa total satuan pendidikan di Indonesia yaitu sekolah dan madrasah ada 219. 876 buah. Dari jumlah itu yang sudah terjangkau listrik \& internet sebanyak 179,097 buah atau (82\%), yang tersedia listrik namun tidak tersedia internet sebanyak 33,227 buah atau (15\%), serta tidak tersedia listrik dan tidak tersedia internet ada 7,552 (3\%). Sehingga total ada 40.779 lembaga atau 18\% yang tidak terjangkau internet dan atau listrik (Kemendikbud, 2020a). Itu gambaran keterjangkauan internet sampai di sekolah, padahal pada masa Covid-19 ini posisi guru dan murid tidak di sekolah malainkan di rumah masing-masing. Jika posisi sekolah kebanyakan lebih terjangkau dibanding rumah-rumah penduduk, maka jumlah siswa yang tidak terjangkau internet masih lebih besar dari $20 \%$.

Kondisi tersebut tampaknya berbeda dengan di Cina yang telah sanggup menyediakan infrastruktur pendukung e-learning di sekolah dan universitas dengan lebih baik. Sejak beberapa dekade terakhir Pemerintah Cina telah membangun sejumlah proyek nasional untuk menyiapkan infrastruktur e-learning di sekolah bahkan membuat proyek sekolah online (Wang dkk., 2009). 
Sebenarnya tingkat penetrasi internet di Provinsi Jawa Tengah sudah cukup tinggi yaitu $71,4 \%$, artinya $71,4 \%$ penduduk di Jawa Tengah sudah terjangkau akses internet. Kondidi di Jawa Tengah masih lebih baik dari rata-rata tingkat penetrasi internet secara nasional yang baru mencapai 64,8\% (Association, 2018). Penetrasi internet di Indonesi juga masih lebih baik dari pada tingkat penetrasi internet secara global yang baru menjangkau $60 \%$ dari total penduduk global (Ramadhan, 2020).

Pengakuan guru PAUD di Jawa Tengah terkait ketersediaan smartphone (apakah milik orang tuanya atau milik siswanya sendiri) masih menjadi kendala karena banyak yang belum memilikinya, dan hal ini perlu dilakukan konfirmasi ulang. Karena kondisi ini jauh berbeda dengan kondisi di provinsi Daerah Istimewa Yogyakarta (DIY). Di DIY 94\% anak PAUD usia TK 4-6 tahun sudah menggunakan smartphone (Zaini dan Soenarto, 2019). Salah satu alasan tingginya tingkat penggunaan smartphone dan tablet di PAUD adalah sebagai sarana pengenalan teknologi informasi dan komunikasi. Namun penelitian ini tidak mengungkapkan apakah penggunakan smartphone tersebut juga digunakan sebagai alat pembelajaran atau tidak. Bisa jadi orang tua siswa PAUD di Jawa Tengah telah memiliki smartphone tapi bisa digunakan mendukung anaknya dalam pembelajaran. Pada saat masa pandemi Covid-19 ini banyak orang tua yang bekerja di rumah sehingga perangkatnya juga digunakan untuk bekerja. Artinya ini juga kendala ketersediaan perangkat pembelajaran.

Kebanyakan anak PAUD menggunakan gadget untuk bermain saja dan bukan untuk pembelajaran (Pebriana, 2017). Padahal perangkat elektronik dan gadget dapat dimanfaatkan oleh orang tua untuk mengenalkan pelajaran kepada anak PAUD. Penelitian menunjukkan bahwa anak yang diajarkan komputer dasar lebih terampil pada pembelajaran (Taufik dkk., 2019). Apa ang bisa diajarkan kepada anak PAUD melalui perangkat elektronik, antara lain mengetik, membuat tabel, menggambar, belajar matematika, dan mengarang cerita (Setyaji dkk., 2015). Pengunaan gadget untuk pembelajaran harus memperhitungkan efek negatifnya. Efek negatif gadget antara lain sebanyak $40 \%$ anak akan mengamuk jika tidak diberikan gadget. Walaupun $22 \%$ orang tua punya tujuan agar anak pintar dengan diberikan gadget namun hanya $1 \%$ saja anak pengguna gadget mendapatkan prestasi di sekolah (Novianti dan Garzia, 2020).

Hasil survey menunjukkan bahwa 29\% penduduk Indonesia belum memiliki handphone. Sebesar $28 \%$ penduduk memiki handphone biasa artinya tidak bisa untuk mendukung implementasi e-learning dan yang memiliki smartphone sebesar $42 \%$ (Yanuar, 2019). Survey yang dilakukan KPAI menunjukkan sebesar $15,6 \%$ siswa tak memiliki peralatan elektronik untuk mendukung e-learning (CNN Indonesia, 2020). Kendala kepemilikan perangkat elektronik dalam mendukung e-learning ini juga dilaporkan oleh Kemendikbud bahwa sebesar $40,5 \%$ siswa dan orang tua siswa mengalami kendala kurangnya fasilitas pendukung pembelajaran berupa laptop, gawai, internet, dan listrik (Kemendikbud, 2020a:17-18).

Kendala ketiga adalah kemampuan ekonomi orang tua siswa dan masyarakat secara umum. Dalam situasi pandemi ini banyak masyarakat yang kehilangan pekerjaan atau menurun pendapatnya karena dirumahkan sementara waktu. Rendahnya kemampuan ekonomi mengakibatkan mereka tidak sanggup membeli perangkat elektronik, untuk berlanggakan wifi, atau untuk membeli quota dan paket data.

Laporan BPS Provinsi Jawa Tengah 2019 sebelum masa Covid-19 jumlah penduduk miskin ada 10,8\% setara dengan 3,74 juta orang Jawa Tengah. Dipastikan dampak Covid-19 ini semakin banyak jumlah masyarakat miskin. Mereka besar kemungkinan tidak memiliki smartphone atau sulit untuk membeli quota internet dan paket data untuk mendukung $e$ learning. Masalah ekonomi ini juga ditemukan dalam laporan KPAI bahwa 42,3\% siswa mengalami kendala tidak memiliki quota internet selama belajar di rumah (CNN Indonesia, 2020). 
Kemendikbud juga melaporkan bahwa kemampuan ekonomi guru merupakan hambatan e-learning ini dialami oleh $20 \%$ guru yaitu kurang memadainya jaringan internet/kurangnya quota (Kemendikbud, 2020a:17-18). Kondisi ini segera direspon oleh Mendikbud dengan mengeluarkan petunjuk teknis BOS reguler tahun 2020 yang diperbaharui (Kemendikbud, 2020b). Disebutkan "pembiayaan langganan daya dan jasa dapat digunakan untuk membeli paket data, pulsa, atau layanan pendidikan daring berbayar bagi pendidik dan peserta didik". Para kepala satuan pendidikan segera merespon baik dengan merealokasi anggaran belanja sekolah. Kemendikbud melaporkan bahwa alokasi anggaran sekolah terbesar diberikan untuk fasilitas penunjang guru termasuk diantaranya untuk membeli quota internet mencapai 51\%, menyewa sumber belajar daring mencapai $11 \%$, serta membeli fasilitas penunjang siswa mencapai $4 \%$ (Kemendikbud, 2020a:9). Kendala keuangan, teknis, dan personel juga ditemukan pada pelatihan calon guru di daerah pedesan di Indonesai dalam menggunakan TIK untuk e-learning (Awaludin, 2016).

Dengan demikian dapat disimpulkan bahwa terdapat tiga kendala utama dalam implementasi e-learning di PAUD yaitu kendala pedagogi, kendala teknologi, dan kendala ekonomi. Kendala pedagogi terkait kemampuan guru dan orang tua siswa untuk menggunakan perangkat elektoronik dalam pembelajaran. Kendala teknologi terkait ketersediaan akses internet dan kepemilikan perangkat elektronik dan gadget atau gawai. Kendala ekonomi karena merosotnya pendapatan masyarakat akibat Covid-19 sehingga tidak mampu membeli quota internet atau berlangganan wifi.

\section{SIMPULAN}

Keefektivan rumusan kebijakan e-learning yang dikeluarkan Pemerintah melalui Kemendikbud dan Kemenag disimpulkan sangat efektif baik secara teoretis dan praktis berupa pemahaman para guru. Keefektivan implementasi kebijakan e-learning yang dilaksanakan oleh para guru PAUD belum efektif karena belum siapnya para guru menerapkan e-learning, pilihan media, platform, metode, alat evaluasi, dan rendahnya tingkat interaksi selama proses pembelajaran, serta banyaknya siswa yang merasakan tidak senang. Terdapat tiga kendala utama implementasi e-learning di PAUD yaitu pedagogi, teknologi, dan ekonomi. Disarankan kepada para guru PAUD agar e-learning bisa dimplementasikan secara efektif maka harus disusun RPP dengan memperhatikan tingkat interaksi yang maksimal.

\section{UCAPAN TERIMAKASIH}

Ucapan terima kasih kami sampaikan kepada Pengurus Provinsi GPRI Jawa Tengah dan Pengurus PGRI Kabupaten serta Kota yang telah membantu menyebarkan angket sehingga dapat menjangkau guru di seluruh kabupaten dan kota di Provinsi Jawa Tengah.

\section{DAFTAR PUSTAKA}

Allen, I. E. dan Seaman, J. 2013. Changing course: Ten years of tracking online education in the United States. ERIC. ISBN 0984028838.

Asiah, N. 2016. Inovasi Pembelajaran Pendidikan Agama Islam melalui E-Learning di SMA Budaya Bandar Lampung. Jurnal MUDARRISUNA: Media Kajian Pendidikan Agama Islam, 6, n. 1, p. 77-101. http://dx.doi.org/10.22373/jm.v6i1.894.

Asilestari, P. 2016. Komputer Interaktif sebagai Media Pengajaran Bahasa Inggris pada Anak Usia Dini. Jurnal Obsesi: Jurnal Pendidikan Anak Usia Dini, 2, n. 1, p. 55-62. http://dx.doi.org/10.22373/jm.v6i1.894.

Association, I. I. S. P. 2018. Penetrasi \& Profil Perialku Pengguna Internet Indonesia. 
Awaludin, A. 2016. Connecting the World: The Utilization of ICT for Rural Teacher Education in Indonesia. TARBIYA: Journal of Education in Muslim Society, 3, n. 2, p. 218-226. http:/ / dx.doi.org/10.15408/tjems.v3i2.4983.

Buzzetto-More, N. A. 2007. Advanced principles of effective e-learning. Informing Science. ISSN 1932886028.

Coates, H. 2006. Student engagement in campus-based and online education: University connections. Routledge, ISBN 1134161530.

Fauzan, U. dan Pimada, L. H. 2018. ICT-Based Teaching of English at Madrasah Aliyah in Kalimantan. TARBIYA: Journal of Education in Muslim Society, 5, n. 2, p. 193-211. https://dx.doi.org/10.15408/tjems.v5i2.10414.

Harjanto, T. dan Sumunar, D. S. E. W. 2018. Tantangan Dan Peluang Pembelajaran Dalam Jaringan: Studi Kasus Implementas Elok (E-Learning: Open For Knowledge Sharing) Pada Mahasiswa Profesi Ners. Jurnal Keperawatan Respati Yogyakarta, 5, p. 24-28..

Huang, R., Spector, J. M., dan Yang, J. 2019. Educational Technology: A primer for the 21st centuary. Springer. ISBN 978-981-13-6643-7. https://doi.org/10.1007/978-981-136643-7.

Inoue, Y. 2007. Online education for lifelong learning. IGI Global. ISSN 1599043211.

Irma, C. N., Nisa, K. dan Sururiyah, S. K. 2019. Keterlibatan Orang Tua dalam Pendidikan Anak Usia Dini di TK Masyithoh 1 Purworejo. Jurnal Obsesi: Jurnal Pendidikan Anak Usia Dini, 3, n. 1, p. 214-224. https:/ / doi.org/10.31004/obsesi.v3i1.152.

Johnson, K. dan Manning, S. 2010. Online education for dummies. Canada: John Wiley \& Sons Publishing. ISBN 0470536209.

Juwah, C. 2006. Interactions in online education: Implications for theory and practice. Routledge. ISBN 1134247494.

Kemendikbud. 2020a. Analisis Survey Cepat Pembelajaran Di Rumah Dalam Masa Pencegahan Covid

Https://Drive.Google.Com/Drive/Folders/1cbytwcueszrev_Aynxpiyy1jt8ncsgq1

Diakses 23 April 2020).

Kemendikbud. 2020b. Peraturan Menteri Pendidikan Dan Kebudayaan Republik Indonesia Nomor 19 Tahun 2020 tentang Perubahan atas Peraturan Menteri Pendidikan dan Kebudayaan Nomor 8 Tahun 2020 tentang Petunjuk Teknis Bantuan Operasional Sekolah Reguler. 2020b.

Kemendikbud. 2020c. Surat Edaran Nomor 3 Tahun 2020 Tentang Pencegahan Corona Virus Disease (Covid-19) Pada Satuan Pendidikan.

Kemendikbud. 2020d. Surat Edaran Nomor 4 Tahun 2020 Tentang Pelaksanaan Kebijakan Pendidikan Dalam Masa Darurat Penyebaran Corona Virus Disease (Covid-19).

Kemenag. 2020a. Surat Jendral Pendidikan Agama Islam Kemenag Direktur KSKKMadrasah No, B-686.1/Dj.I/Dt.I.I/Pp.00/03/2020 Tentang Mekanisme Pembelajaran dan Penilaian Madrasah dalam Masa Darurat Pencegahan Penyebaran Covid-19.

Kemenag. 2020b. https:/ / Madrasah3.Kemenag.Go.Id/Elearning/ Diakses 20 April 2020.

Kemenag. 2020c. http://Emispendis.Kemenag.Go.Id/Dashboard/?Content=Data-Statistik diakses 20 April 2020.

KPAI-Komisi Perlindungan Anak Indonesia. 2020a. Sebab Siswa Semakin Termaginalkan Saat Belajar Di Rumah. https://www.kpai.go.id/berita/sebab-siswa-semakintermarginalkan-saat-belajar-dari-rumah diakses 5 Mei 2020.

KPAI-Komisi Perlindaungan Anak Indonesia. 2020b. KPAI-FSGI: 53\% Guru Berorientasi Kurikulum Saat Belajar dari Rumah. https:/ / www.kpai.go.id/berita/ sebab-siswa-semakintermarginalkan-saat-belajar-dari-rumah diakses 5 Mei 2020.

Lynch, M. M. 2002. The online educator: A guide to creating the virtual classroom. Routledge. ISBN 1134542542.

Madjid, A. 2028. Analisis Kebijakan Pendidikan. Yogyakarta: Samudera Biru. 
Mashabi, S. 2020. "Survei Kemen PPPA: 58 Persen Responden Tak Senang Belajar dari Rumah". https://nasional.kompas.com/read/2020/04/11/13511231/survei-kemenpppa-58-persen-responden-tak-senang-belajar-dari-rumah diakses 5 Mei 2020.

Novianti, R. dan Garzia, M. 2020. Penggunaan Gadget Pada Anak; Tantangan Baru Orang Tua Milenial. Jurnal Obsesi: Jurnal Pendidikan Anak Usia Dini, 4, n. 2. https://doi.org/10.31004/obsesi.v4i2.490,

Nugroho, R. 2017. Public Policy: Dinamika Kebijakan, Analisis Kebijakan, dan Manajemen Politik Kebijakan Publik. Jakarta: Elex Media Komputindo.

Nugroho, R. 2014. Metode Penelitian Kebijakan. Yogyakarta: Pustaka Pelajar. ISBN 9786022292470.

Palloff, R. M. dan Pratt, K. 2002. Lessons from the cyberspace classroom: The realities of online teaching. California: John Wiley \& Sons Publishing. ISBN 0787959960.

Pangondian, R. A., Santosa, P. I. dan Nugroho, E. 2019. Faktor-Faktor Yang Mempengaruhi Kesuksesan Pembelajaran Daring Dalam Revolusi Industri 4.0. Seminar Nasional Teknologi Komputer \& Sains (SAINTEKS).

Panjaitan, N. Q., Yetti, E. dan Nurani, Y. 2020. Pengaruh Media Pembelajaran Digital Animasi dan Kepercayaan Diri terhadap Hasil Belajar Pendidikan Agama Islam Anak. Jurnal Obsesi: Jurnal Pendidikan Anak Usia Dini, 4, n. 2, p. 588-596. https://doi.org/10.31004/obsesi.v4i2.404.

Pebriana, P. H. 2017. Analisis Penggunaan Gadget Terhadap Kemampuan Interaksi Sosial Pada Anak Usia Dini. Jurnal Obsesi: Jurnal Pendidikan Anak Usia Dini, 1, n. 1, p. 1-11. https://doi.org/10.31004/obsesi.v1i1.26.

Ramadhan. 2020. Ini Data Pengguna Internet di Seluruh Dunia Tahun 2020, https://teknoia.com/data-pengguna-internet-dunia-ac03abc7476 diakses 10 April 2020.

Rayes, A. dan Salam, S. Internet of things-from hype to reality: the road to digitization. Switzerland AG 2017: Springer Nature, 2019. ISBN 978-3-319-99516-8.

Roach, V. dan Lemasters, L. 2006. Satisfaction with online learning: A comparative descriptive study. Journal of Interactive Online Learning, 5, n. 3, p. 317-332.

Rohita, R. 2020. The Ability of Ece Teachers to Use ICT in The Industrial Revolution 4.0. Jurnal Obsesi: Jurnal Pendidikan Anak Usia Dini, 4, n. 2, p. 502-511. https://doi.org/10.31004/obsesi.v4i2.339.

Rostaminezhad, M., Mozayani, N., Norozi, D., dan Iziy, M. (2013). Factors related to elearner dropout: Case study of IUST elearning center. Procedia-Social and Behavioral Sciences, 83, p. 522-527. https://doi.org/10.1016/j.sbspro.2013.06.100.

Sari, K. M. dan Setiawan, H. 2020. Kompetensi Pedagogik Guru Dalam Melaksanakan Penilaian Pembelajaran Anak Usia Dini. Jurnal Obsesi: Jurnal Pendidikan Anak Usia Dini, 4, N. 2, P. 900-912. https:// doi.org/10.31004/obsesi.v4i2.478,

Setyaji, A., Iskak, A., Sukmaningrum, R. dan Hawa, F. 2015. Komputer Interaktif Sebagai Media Pengajaran Bahasa Inggris Pada Anak Usia Dini. E-Dimas: Jurnal Pengabdian Kepada Masyarakat, 6, N. 1, P. 1-12. http://dx.doi.org/10.26877/e-dimas.v6i1.794.

Sugiyono. 2017. Metode Penelitian Kebijakan (Pendekatan Kuantitatif, Kualitatif, Kombinasi, RED, dan Penelitian Evaluasi). Bandung: Penerbit Alfabeta. ISBN 9786022893110.

Suhartanto, H. 2010. Survei 2009: Mutu Situs E-Learning Sekolah Indonesia Masih Sangat Minim. Jurnal Sistem Informasi, 6, n. 1, p. 80-83. https:// doi.org/10.21609/jsi.v6i1.280.

Sum, T. A. dan Taran, E. G. M. 2020. Kompetensi Pedagogik Guru Paud Dalam Perencanaan Dan Pelaksanaan Pembelajaran. Jurnal Obsesi: Jurnal Pendidikan Anak Usia Dini, 4, N. 2. https://doi.org/10.31004/obsesi.v4i2.287.

Swan, K. 2003. Learning Effectiveness Online: What The Research Tells Us. Elements Of Quality Online Education, Practice And Direction. 4, N. 1, P. 13-47. 
Taufik, A., Apendi, T., Saidi, S. dan Istiarsono, Z. 2019. Parental Perspectives On The Excellence Of Computer Learning Media In Early Childhood Education. Jurnal Pendidikan Usia Dini, 13, N. 2, P. 356-370. https://doi.org/10.21009/JPUD.132.11.

Tilaar, H. dan Nugroho, R. 2009. Kebijakan Pendidikan: Pengantar Untuk Memahami Kebijakan Pendidikan Dan Kebijakan Pendidikan Sebagai Kebijakan Publik. Yogyakarta: Pustaka Pelajar.

Wang, Q., Zhu, Z., Chen, L., dan Yan, H. 2009. E-learning in China. Campus-Wide Information Systems, 26, n.2. https:// doi.org/10.1108/10650740910946783.

Winter, J., Cotton, D., Gavin, J., dan Yorke, J. D. 2010. Effective E-Learning? Multi-Tasking, Distractions And Boundary Management By Graduate Students In An Online Environment. Alt-J, 18, N. 1, P. 71-83. https://doi.org/10.1080/09687761003657598.

Yanuar. 2019. Survei Kepemilikan Smartphone, Indonesia Peringkat ke-24. https://Tekno.Tempo.Co/Read/1181645/Survei-Kepemilikan-SmartphoneIndonesia-Peringkat-Ke-24/Full\&View=Ok Diakses 21 April 2020.

Zaini, M. dan Soenarto, S. 2019. Persepsi Orangtua Terhadap Hadirnya Era Teknologi Digital Di Kalangan Anak Usia Dini. Jurnal Obsesi: Jurnal Pendidikan Anak Usia Dini, 3, N. 1, P. 254-264. https://doi.org/10.31004/obsesi.v3i1.127. 